Sokolov, of the State Committee for Utilization of Atomic Energy, whose main interest is in particle detectors and instrumentation for physics experiments.

\section{U.S. Nuclear Power Projects}

THE third edition of Fact Sheets on U.S. Nuclear Power Projects is a complete revision of the sheets first published in December 1958 and revised in June 1960 (Pp. iii +51. New York: Bozell and Jacobs, Inc., 230 Park Avenue, 1961). The reactors listed are classified by coolant. The water-cooled reactors include five pressurized and eight boiling-water reactors. The sodium-cooled reactors comprise two moderated and two fast-breeder reactors, and one organic-cooled and three gas-cooled reactors are also listed. The introductory article discusses the approach to nuclear power development in the United States which has not been, and is not, aimed primarily at producing kilowatts, but is designed to develop technical information for the construction of commercial plants by the electrical utility industry. At least 133 investor-owned electricity companies in the United States of America are actively engaged in civilian nuclear power projeets, including plants in operation; under construction, or under contract, or planned; or in study, research, and development projects; a complete alphabetical reference list of the projects is given at the end of the Fract Sheets.

\section{New Hope for African Wildlife}

Great concern has been felt in recent years about the accelerating rate of destruction of wild fauna, flora and habitat in Africa, without regard to their value as a continuing economic, scientific and cultural resource. It is feared that by 1970 several of the largest land mammals in Africa will not survive in a wild state. The smaller wild creatures are already under constant threat as the New Africa expands and demands on its natural resources grow. At the 1960 Warsaw Congress of the International Union for the Conservation of Nature it was recognized that the crux of the problem is to persuade the people of the New Africa to appreciate the value of their wild life not only in relation to the growth and prosperity of their country but also for the sake of future generations. It was at this Congress that the African Special Project was planned in three stages: (1) survey of problems; (2) conference to discuss possible solutions; (3) operational work to implement the solutions. Stage 1, which has already been completed, consisted of a survey carried out in sixteen African countries. Stage 2 has been planned and prepared in detail. The conference on "The Conservation of Nature and Natural Resources in Modern African States" will be held in Arusha, Tanganyika, during September 5-12. It is organized jointly by the International Union with the Commission for Technical Co-operation in Africa. For practical reasons the number of delegates had to be limited, but will include representatives of 25 governments. A number of 'fellowships' has been provided so that selected. Africans of the younger generation can participate. Further information can be obtained from the Press Officer to the Arusha Conference, Ian S. MacPhail, 20 Belgrave Square, London, S.W.1.

\section{Recent Map Publications by the Ordnance Survey of Great Britain}

ON August 1, the last six sheets were published by the Ordnance Survey of Great Britain, completing the Seventh Series of the One Inch to One Mile Maps, and for the first time the whole of Great Britain is covered by a single series of maps at this scale, in which all sheets are similar in projection, size and style. The six sheets are: Sheet 1, Shetland Islands (Yell and Unst); Sheet 2, Shetland Islands (North Mainland); Sheet 3, Shetland Islands (Lerwick); Sheet 4: Shetland Islands (South Mainland); Sheet 188, Torquay; Sheet 190, Truro and Falmouth. At the same time, six publications of the new post-war seriea of One Inch Tourist Sheets have been published: North York Moors; Peak District; Wye Valley and Lower Severn; Lake District; Lorn and Lochaber; Loch Lomond and the Trossachs. With the exception of the sheet Wye Valley and Lower Severn, where relief is depicted by contours and layer tints, the sheets in this series show relief by various combinations of layer tints and hill shading, which give an immediate impression of ground shapes even to the inexperienced map reader. In other respects, the style remains generally the same as that used for the One Inch Seventh Series. Copies of all sheets are available in three styles from all Ordnance Survey agents and H.M. Stationery Office bookshops (Tourist Sheets: paper flat, 58. ; paper folded in covers, 78. ; mounted on linen in covers, 98. Seventh Series: paper flat, 4s. 6d. ; paper folded in covers, 58. 6d. ; mounted on linen in covers, $78.6 d$.).

\section{Problems of Psychology}

A NEW quarterly journal (Problems of Psychology, Nos. 1 and 2. Pergamon Press, 1960) aims at pub. lishing a selection of papers in translation from Voprosy Psikhologii, the Russian psychological journal founded in 1955 . Dr. N. O'Connor, who is acting as translation editor, states in his foreword that he hopes to choose papers which will be both representative of Soviet psychology and at the same time of special interest to English readers. The present issue contains papers on a wide variety of topics, ranging from the role of the cerebral cortex in the perception of flicker to the psychology of a man with prodigions powers of memory. Of particular interest to English psychologists is Dr. E. N. Sokolov's extremely ingenious probability model of tactile perception. Although rather uneven, this new psychological journal will be widely welcomed.

\section{The Royal Scottish Museum}

The annual report of the Royal Scottish Museum (Pp. 29. Edinburgh: Royal Scottish Museum, 1961), Edinburgh, for 1960 will be the last to appear under the control of the present director, Dr. D. A. Allan, for he retires shortly (see Nature, August 12, p. 648). The report indicates progress in all directions especially as regards the carefully planned building operations. The lecture-theatre block approaches completion, fluorescent lighting has been installed in the store rooms, and a further series of exhibition galleries have been redecorated in what is now regarded as the standard colour scheme. Considerable progress has also been made on paper with the replanning of the north-east and north-west wings facing Chambers Street. The introduction of automatic stoking and thermostatic control has led to difficulties in securing adequate humidity, but further experiments to remedy this are being carried out. The consequent diminution in work, dust and dirt in the basement storage is marked and welcomed. As usual, temporary exhibitions have been a valuable feature in the activities of this Museum, and a total annual attend- 